\title{
APRESENTAÇÃO DOSSIÊ - EDUCAÇÃO POPULAR E SABERES TRADICIONAIS EM DIFERENTES TERRITORIALIDADES
}

\section{PRESENTATION DOSSIER - POPULAR EDUCATION AND \\ TRADITIONAL KNOWLEDGE IN DIFFERENT TERRITORIALITIES}

\author{
Everaldo Fernandes da Silva ${ }^{1}$ \\ Eduardo Jorge Lopes da Silva ${ }^{2}$
}

\section{APRESENTAÇÃO}

No cenário de negacionismo da Ciência, da preconização do terraplanismo e de polarizações na política, os movimentos sociais e a sociedade civil organizada sentem-se, ao mesmo tempo, intimidados e convidados a buscar alternativas crítico-propositivas e de resistência em vários campos e espectros. O país vive a pandemia causada pela COVID-19, que já matou mais de 570 mil pessoas no Brasil. Caso existisse um projeto de nação pautada numa política pública de saúde comprometida com a vida de todos/as brasileiros/as, certamente, o Ministério da Saúde teria agido rápido em resposta aos e-mails de fabricantes de vacinas, que desejavam fazer do Brasil uma vitrine para mundo de que é possível vencer e superar esta pandemia.

Mas, ao contrário disso, os governantes da esfera federal optaram pelo negacionismo, subtraindo aos milhares de brasileiros/as e seus familiares o direito à vida. É nesse contexto político que o Brasil vivencia, que a Educação Popular se torna ainda mais importante e necessária, especialmente, pelos princípios que ela defende, ou seja, uma educação a favor da

\footnotetext{
${ }^{1}$ Atualmente é Professor Adjunto IV no Núcleo de Formação Docente da Universidade Federal de Pernambuco, Campus Agreste. Integrante do corpo docente permanente do Programa de Pós-Graduação em Educação Contemporânea (PPGEDUC). Doutor em Educação pela Universidade Federal de Pernambuco. e-mail: everaldofernandes.silva@gmail.com

2 Atualmente é Professor no Centro de Educação, Departamento de Fundamentação da Educação e no Programa de Pós-Graduação em Educação da Universidade Federal da Paraíba. Doutor em Educação pela Universidade Federal de Pernambuco. e-mail: eduardojorgels@gmail.com
} 
libertação e emancipação dos sujeitos humanos. Outrossim, não esqueçamos que esta concepção de Educação Popular tem em Paulo Freire seu emblemático pensador. De acordo com Silva (2018, p. 269-270), Paulo Freire define que,

[...] em toda extensão de suas ideias, advoga a educação como dispositivo que afirma o homem como homem [...]. Para ele a educação é capaz de fomentar milagres, pelos quais os seres humanos possam conviver e viver no respeito, na tolerância e na amorosidade das relações entre todos os sujeitos humanos, inclusive sendo capaz de transcender da sua imanência para se relacionar com o infinito, com o divino, desde que, nesse caso, a educação não seja para domesticar, submissão ou resignação, pois ela perderia seu sentido.

No ano centenário desse pensador dos oprimidos, a Revista Debates Insubmissos apresenta o Dossiê Educação Popular e Saberes Tradicionais em Diferentes Territorialidades, com a intenção de despertar o aprofundamento de novas discussões, olhares e compreensões acerca das intelecções e práticas da Educação Popular e da presença e contribuições dos saberes tradicionais/populares em diferentes contextos e situações que ultrapassam os olhares costumeiros dessas abordagens epistemológicas nos espaços nãoescolares, nos movimentos sociais, nas Ongs e também na educação de jovens e adultos em espaços não escolares, sem em nada desmerecer as contribuições historicamente configuradas nos muros da educação formalmente institucionalizada.

Nessa direção, temos o artigo de João Anzanello Carrascoza, Operação Flipinha: encontro do sonhador e do cientista em terra firme. $O$ autor apresenta o seu intento epistemológico a partir da Festa Literária Internacional de Paraty, em que investigou aspectos comunicacionais e educacionais associados ao consumo desse evento literário, mas, sobremaneira, dando destaque solucionador à inter-relação da ciência com a poesia. $\mathrm{O}$ mais significativo deste texto é a ousadia do autor em abordar a Flip cientificamente sem abdicar da sua experiência de organização de sentidos e da sua maestria poética.

O segundo artigo, Museus: Territórios de Brinquedos e Brincadeiras como Difusão Extensionista de Saberes, Memórias e Práticas, de Adriana Isabel Rodrigues Marcos, Luís Távora Furtado Ribeiro e Edvar Ferreira Basílio, traz uma reflexão sobre o ensino de história, com o uso de vários materiais e constructos artesanais em museus-territórios de brinquedos e brincadeiras populares. O dado contribuinte e novidadeiro deste estudo consiste, a nosso ver, 


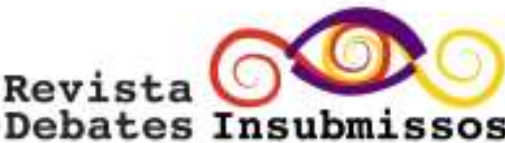

em preconizar uma possível pedagogia dos museus em que a leveza, a curiosidade, a estética, a memória e a construção dos saberes cruzam-se com a ludicidade como ingrediente latente das aprendizagens. Os museus, para os próprios autores, é um espaço onde o brincar oportuniza estratégias relacionais com o público, objetivando novas aprendizagens e uma "educação museal".

O terceiro artigo, A ação docente e a identidade regional de estudantes da EJA, das autoras Ana Lúcia Madson Gomboeff, Maria Emiliana Lima Penteado e Patrícia da Silva Santos, analisa o relato de uma ex-professora da EJA, "sobre uma proposta de ação docente pautada no diálogo, na tradição oral, no folclore e no resgate da identidade regional dos estudantes". Após a análise, as autoras concluem que a ação pedagógica da professora ancorase nos pressupostos, princípios e fundamentos da Educação Popular em que a humanização, as aprendizagens contextualizadas e a autoria dos sujeitos populares têm assentos de legitimidade e de serem produtores do conhecimento a partir do lugar que existem e se pronunciam.

No quarto artigo, Um Novo Possível pela Via da Educação Popular na Formação

Continuada de Professores da Educação de Jovens e Adultos, os autores Eduardo Jorge Lopes da Silva e Adriana Bastos Oliveira apresentam um recorte de pesquisa, em nível de mestrado, sobre a formação continuada de professores da EJA de uma escola pública municipal de Joao Pessoa-PB, sob a ótica da Educação Popular. Esta pesquisa destaca a presença da Educação Popular nos espaços escolares tomando assento e exercendo influência na formação continuada destes docentes que, objetivo e subjetivamente, compreendem a imbricação entre educação e formação integral dos sujeitos, cuja base estrutura-se na humanização, na construção coletiva e nos múltiplos territórios e modalidades de se educar para ser, conviver e agir para existir, para gentificar-se.

E, o quinto artigo, Educação Popular, Saberes Tradicionais e Debates Insubmissos: um diálogo com Carlos Rodrigues Brandão, nos brinda com uma conversa reflexiva com Brandão, um dos ícones da Educação e da Cultura Popular. Este diálogo foi realizado por Valéria Oliveira de Vasconcelos e Renata Evangelista Oliveira. Segundo as interlocutoras, foi realizado um triálogo no qual se destacou: "a relação entre a Educação Popular, os saberes 
tradicionais e populares, a relação com o campo e o rural, e os caminhos trilhados, considerando a atual conjuntura política, econômica e social em que se encontra nosso país e o delicado momento histórico causado pela Pandemia de Covid 19”.

A todos/as leitores/as da Revista Debates Insubmissos, desejamos que os temas em diferentes territorialidades da Educação Popular possam resultar numa inteligibilidade crítica, numa possibilidade de forjar subjetivações libertadoras e comprometidas, além de potencializar a esperança freireana, perante as cenas dramáticas e cotidianas dos negacionismos, do cinismo político, da beligerância e da indiferença às dores e sofrimentos humanos. A Educação Popular e os Saberes Tradicionais vêm ao nosso encontro na perspectiva de que, em diferentes territórios e modalidades, os sonhos e as iniciativas brotam, indicando um Brasil inédito possível. Fica aqui a ressonância poética: “Apesar de você, amanhã há de ser outro dia” (Chico Buarque) com a firme tarefa convidativa do ator Paulo Gustavo de que: "Não se esqueçam que o riso é uma arma de resistência" (in memoriam).

\section{REFERÊNCIAS}

BUARQUE, Chico. Apesar de você. Disponível em:

https://www.google.com/search?client=firefox-b$\mathrm{d} \& \mathrm{q}=$ apesar $+\mathrm{de}+\mathrm{voc} \% \mathrm{C} 3 \% \mathrm{AA}+\mathrm{amanh} \% \mathrm{C} 3 \% \mathrm{~A} 3+\mathrm{h} \% \mathrm{C} 3 \% \mathrm{~A} 1+\mathrm{de}+\mathrm{ser}+$ outro + dia Acesso em: 15 de ago. 2021.

SILVA, Eduardo Jorge Lopes da. Paulo Freire e a Educação Popular Libertadora dos Homens/Mulheres. In: LOPES, Eduardo Jorge; AMORIM, Roseane Maria de (Orgs.). Paulo Freire: culturas, ética e subjetividade no ensinar e aprende. João Pessoa: Editora do CCTA, 2018. 